\title{
Characterization of Brown Streak Virus-Resistant Cassava
}

\author{
Ravi B. Anjanappa, ${ }^{1}$ Devang Mehta, ${ }^{1}$ M. N. Maruthi, ${ }^{2}$ Edward Kanju, ${ }^{3}$ Wilhelm Gruissem, ${ }^{1}$ \\ and Hervé Vanderschuren ${ }^{1,4}$ \\ ${ }^{1}$ Department of Biology, Plant Biotechnology, ETH Zurich, Zurich, Switzerland; ${ }^{2}$ Natural Resources Institute (NRI), University \\ of Greenwich, Chatham Maritime, Kent ME4 4TB, U.K.; ${ }^{3}$ International Institute of Tropical Agriculture, P.O Box 34441, Dar \\ es Salaam, Tanzania; and ${ }^{4}$ AgroBioChem Department, Gembloux Agro-Bio Tech, University of Liège, 4000 Liège, Belgium
}

Accepted 18 March 2016.

Cassava brown streak disease (CBSD) has become a major constraint to cassava production in East and Central Africa. The identification of new sources of CBSD resistance is essential to deploy CBSD mitigation strategies, as the disease is progressing westwards to new geographical areas. A stringent infection method based on top cleft-grafting combined with precise virus titer quantitation was utilized to screen 14 cassava cultivars and elite breeding lines. When inoculated with mixed infections of Cassava brown streak virus (CBSV) and Ugandan cassava brown streak virus (UCBSV), the scions of elite breeding lines KBH 2006/18 and KBH 2006/26 remained symptomfree during a 16-week period of virus graft inoculation, while susceptible varieties displayed typical CBSD infection symptoms at 4 weeks after grafting. The identified CBSD resistance was stable under the coinoculation of CBSV and UCBSV with cassava geminiviruses. Double-grafting experiments revealed that transmission of CBSV and UCBSV to CBSD-susceptible top scions was delayed when using intermediate scions of elite breeding lines KBH 2006/18 and KBH 2006/26. Nonetheless, comparison of virus systemic movement using scions from KBH2006/18 and a transgenic CBSD resistant 60444 line (60444-Hp9 line) showed that both CBSV and UCBSV move at undetectable levels through the stems. Further, protoplastbased assays of virus titers showed that the replication of CBSV is inhibited in the resistant line $\mathrm{KBH2006/18}$, suggesting that the identified CBSD resistance is at least partially based on inhibition of virus replication. Our molecular characterization of CBSD resistance in cassava offers a robust virus-host system to further investigate the molecular determinants of CBSD resistance.

Cassava (Manihot esculenta Crantz) is a food security crop in Africa due to its relatively good performance under difficult growing conditions and the capacity of its starch-rich storage roots to be maintained in the ground, allowing progressive harvest (Fermont et al. 2010). Despite its superior agronomic performance under adverse conditions cassava production is severely constrained by viral diseases. Of these, cassava mosaic disease (CMD) and cassava brown streak disease (CBSD) are the most widespread and severe cassava diseases in

Corresponding author: H. Vanderschuren; E-mail: hvanderschuren@ ethz.ch or herve.vanderschuren@ulg.ac.be; Telephone: +41 446328725 or +3281622571.

*The $\boldsymbol{e}$-Xtra logo stands for "electronic extra" and indicates that nine supplementary figures and four supplementary tables are published online.

(c) 2016 The American Phytopathological Society
Africa (Patil and Fauquet 2009). While CMD has long been viewed as the main constraint to cassava production in Africa (Seif 1982; Otim-Nape et al. 1997), CBSD has recently become a major problem, due to its reemergence in East Africa and its rapid spread into new geographical areas in central African countries (Alicai et al. 2007; Bigirimana et al. 2011; Mulimbi et al. 2012; Patil et al. 2015).

Viral disease management in cassava fields has mostly relied on the identification of existing sources of virus resistance, the introgression of virus resistance traits into farmer-preferred cultivars, and the deployment of virusresistant varieties in the field (Thresh and Cooter 2005). These strategies have been particularly important for mitigating the impact of CMD in the CMD pandemic regions of Africa (Legg et al. 2006). However, the CMD-resistant cultivars and landraces deployed in CMD-affected regions were not tested for resistance to CBSD. They later appeared to be susceptible to CBSD (Legg et al. 2006), which may have facilitated the spread of CBSD in East and Central Africa during the last two decades. Thus, renewed measures to identify, characterize, and preserve CBSD resistance in cassava germplasm are required for sustainable disease management strategies.

Cassava brown streak virus (CBSV) was confirmed to be the causal agent of CBSD in the 1950s (Lister 1959), but it was only recently that CBSV was taxonomically grouped into the genus Ipomovirus (family Potyviridae) (Monger et al. 2001) and that the full genome sequence became available (Mbanzibwa et al. 2009a). Sequencing efforts of CBSD-infected cassava samples from different regions in East Africa led to the identification of two viral species (Mbanzibwa et al. 2009b; Monger et al. 2010; Ndunguru et al. 2015; Winter et al. 2010), now referred to as Cassava brown streak virus (CBSV) and Ugandan cassava brown streak virus (UCBSV). Despite their initial identification from distinct geographical zones, co-occurrence of CBSV and UCBSV has been reported, and recent outbreaks of CBSD are not uniquely associated with a particular virus species (Legg et al. 2011; Mbanzibwa et al. 2011a).

CBSD resistance originating from Manihot glaziovii, Manihot melanobasis, and a few cassava varieties of Brazilian origin was initially reported in the cassava improvement programs at the Amani Research Station throughout the 1940s and 1950s (Hillocks et al. 2001; Jennings and Iglesias 2002). However, recent evaluations of the cassava germplasm have identified only tolerance rather than resistance to CBSD (Legg et al. 2011). It remains unclear whether the CBSD resistance was lost through selective breeding for CMD (Hillocks et al. 2001) or that initial reports of CBSD resistance were actually referring to CBSD tolerance due to inconsistent use of the terminology (Cooper and Jones 1983). 
Leaf and root symptoms triggered by CBSD infection vary largely in terms of localization and intensity in susceptible and tolerant cassava varieties (Mohammed et al. 2012; Winter et al. 2010). Molecular tools available today for detecting and discriminating CBSV species offer new opportunities to better determine the tolerance and resistance levels to CBSV as well as to investigate cassava response to CBSD (Abarshi et al. 2010, 2012; Mbanzibwa et al. 2011a; Moreno et al. 2011; Tomlinson et al. 2013). Importantly, such tools should also be used to investigate the robustness of CBSD resistance when exposed to mixed infections of ipomoviruses and cassava mosaic geminivirus (CMG), which do co-occur in several cassava-growing regions (Alicai et al. 2007; Legg et al. 2011).

Here, we report the screening of selected cassava farmerpreferred varieties and elite breeding lines for CBSD resistance, using a robust and reproducible inoculation method in combination with selected CBSV and UCBSV isolates. We monitored the viral replication titer in order to determine the level of resistance and performed coinoculation of CBSV and UCBSV isolates with a severe CGM isolate, to test the robustness of CBSD resistance under mixed virus infection conditions. We also used double-grafting experiments and protoplast-based assays in order to study the resistance mechanism exhibited by the elite breeding line KBH 2006/18, identified as resistant against the CBSV and UCBSV isolates tested in the present study. This

Table 1. Cassava brown streak disease (CBSD) resistance screening on selected cassava varieties and elite breeding lines

\begin{tabular}{lccc}
\hline Accession $^{\mathbf{a}}$ & Scions/grafts $^{\mathbf{b}}$ & $\begin{array}{c}\text { Symptom } \\
\text { appearance }^{\mathbf{c}}\end{array}$ & $\begin{array}{c}\text { Foliar } \\
\text { symptom } \\
\text { severity }^{\mathbf{d}}\end{array}$ \\
\hline MTAI 25 & $3 / 3$ & 4 to 6 & ++++ \\
SC 8 & $3 / 3$ & 4 to 6 & +++ \\
60444 & $3 / 3$ & 4 to 6 & +++ \\
TMS 30572 & $2 / 2$ & 4 to 6 & +++ \\
Albert & $3 / 3$ & 4 to 6 & +++ \\
Ebwanatareka & $3 / 3$ & 4 to 6 & +++ \\
UMUCASS 33 & $4 / 4$ & 4 to 6 & ++ \\
TME 3 & $4 / 4$ & 6 to 8 & ++ \\
TME 7 & $4 / 4$ & 6 to 8 & ++ \\
KBH 2006/12 & $3 / 3$ & 6 to 8 & ++ \\
KBH 2002/363 & $3 / 3$ & 6 to 8 & + \\
TMS 30001 & $1 / 3$ & 7 to 9 & + \\
KBH 2006/18 & $0 / 3$ & No symptoms at 16 wag & No symptoms \\
KBH 2006/26 & $0 / 3$ & No symptoms at 16 wag & No symptoms \\
\hline TSC
\end{tabular}

a $\mathrm{SC}=$ South China, TMS = tropical Manihot species, TME = tropical Manihot esculenta, and $\mathrm{KBH}=$ Kibaha.

${ }^{b}$ Number of symptomatic scions/number of grafts.

${ }^{c}$ Weeks after grafting (wag) that symptoms appeared.

${ }^{\mathrm{d}}$ Visual assessment of CBSD symptoms on first two fully expanded leaves of grafted scions at 8 wag. CBSD symptoms represent up to $10 \%(+), 10$ to $30 \%(++), 30$ to $60 \%(+++)$, above $60 \%(++++)$ of leaf surface. first comprehensive characterization of CBSD resistance in cassava under controlled conditions opens new perspectives of investigating the molecular mechanism of CBSD resistance and screening for resistant elite breeding lines and farmer-preferred cassava varieties.

\section{RESULTS}

Identification of cassava genotypes resistant to CBSD.

Farmer-preferred cassava varieties were selected based on their geographical origin and reported CMD resistance (Supplementary Table S1). Our selection also included elite breeding lines from the Great Lakes Cassava Initiative (Catholic Relief Services 2012). Disease-free scions were grafted onto cassava variety 60444 rootstocks carrying a mixed infection of CBSV (TAZ-DES-01) and UCBSV (TAZ-DES-02). The top cleft-grafting method (Supplementary Fig. S1), previously established in our laboratory (Moreno et al. 2011; Vanderschuren et al. 2012), resulted in a high survival rate (over 90\%) and $100 \%$ CBSD infection in control 60444 scions. CBSD foliar symptoms appeared in scions from susceptible varieties at 4 weeks after grafting (wag) (Table 1). The symptom severity differed between susceptible varieties. In particular, variety MTAI 25 was highly susceptible with early CBSD symptoms followed by dieback of the scions - an observation previously made in the field on highly susceptible cassava varieties (Hillocks et al. 1996, 2001). Varieties SC 8, 60444, and TMS 30572 also showed an early onset of CBSD symptoms (Supplementary Fig. S2A), but the scions survived during the 16-week observation period. Varieties TME 3, TME 7, UMUCASS 33, KBH 2006/12, and KBH 2002/363 developed mild CBSD symptoms between 4 to 8 wag. The appearance of symptoms on scions of TMS 30001 (a variety that developed few symptoms of restricted distribution when infected with CMGs [Thresh and Cooter 2005]) was either delayed or not observed in all scions. No CBSD symptoms could be detected in scions of KBH 2006/18 and $\mathrm{KBH} 2006 / 26$, even at 16 wag. Results from four independent grafting experiments are compiled in Table 2 (second column). The reported CBSD resistance results in controlled greenhouse conditions are consistent with results from the Great Lakes Cassava Initiative, in which the two elite breeding lines, KBH 2006/18 and 2006/26, were identified as CBSD-resistant breeding lines in the field (Catholic Relief Services 2012). However, no further data have been reported on these varieties.

At completion of one grafting experiment, scions from 60444 , $\mathrm{KBH}$ 2006/18, and KBH 2006/26 were propagated via stem cuttings in the glasshouse. Cuttings of KBH 2006/18 (84\%) and KBH 2006/26 (92\%) displayed a higher survival rate compared with $60444(60 \%)$ for mixed infection of CBSVs (Supplementary Table S2). All 60444 cuttings showed CBSD symptoms, while all propagated KBH 2006/18 and KBH 2006/26 cuttings remained symptom-free.

Table 2. Summary of grafting experiments ${ }^{\mathrm{a}}$

\begin{tabular}{lccc}
\hline & CBSV [TAZ-DES-01] + UCBSV & UCBSV & CBSV [MZ:Nam1-1:07] + UCBSV \\
[TAZ-DES-02] & [UG:Kab4-3:07] & Side grafting \\
[UG:Kab4-3:07] & Albert \\
\hline Inoculation method & Top cleft grafting & Top cleft grafting & \\
Rootstock & 60444 & AR34.2 & - \\
Accessions & & & $0 / 4^{\mathrm{c}}$ \\
60444 & $32 / 32^{\mathrm{c}}$ & $3 / 3^{\mathrm{c}}$ & $0 / 4$ \\
KBH 2006/18 & $0 / 30$ & $0 / 3$ & $3 / 3$ \\
KBH 2006/26 & $0 / 30$ & $0 / 3$ & - \\
TMS 30001 & $11 / 23$ & $0 / 3$ & $3 / 3$ \\
Mock & $0 / 21$ & $0 / 4$ & - \\
Albert & - & - & \\
\hline
\end{tabular}

\footnotetext{
a Symptoms were observed at 8-16 weeks after grafting.

${ }^{\mathrm{b}}$ Results in this column were compiled from four independent experiments.

${ }^{c}$ Values represent the number of symptomatic scions/number of grafts.
} 
We reported earlier a correlation between CBSD symptom severity and virus titers (Moreno et al. 2011). Virus titers were monitored in 60444, KBH 2006/18, and KBH 2006/26, to investigate the presence of CBSVs in symptom-free plants. We quantitated virus levels by reverse transcription-quantitative polymerase chain reaction (RT-qPCR) using the cassava $P P 2 A$ gene as an internal control (Moreno et al. 2011). Quantitation of virus titers in 60444 rootstocks confirmed that scions were exposed to high levels of infection pressure (Supplementary Fig. S3). Neither CBSV (TAZ-DES-01) nor UCBSV (TAZDES-02) were detectable at $8 \mathrm{wag}$ in the scions of $\mathrm{KBH}$ 2006/18 and KBH 2006/26 grafted onto 60444 rootstocks carrying mixed infection of CBSVs (Fig. 1 A and B). Both CBSV (TAZ-DES-01) and UCBSV (TAZ-DES-02) were detected in 60444 scions that showed typical CBSD symptoms. As previously observed (Vanderschuren et al. 2012), UCBSV was, on average, detected at higher titers than CBSV in 60444 scions.

\section{Identified CBSD resistance}

is independent of the grafting procedure.

Top cleft-grafting on virus-infected rootstocks has proven highly effective for CBSV and UCBSV transmission, with $100 \%$ infection rates in control plants (Moreno et al. 2011) (Table 2). In order to investigate virus replication in roots, we performed top-grafting of CBSV (TAZ-DES-01)- and UCBSV (TAZ-DES-02)-infected scions on virus-free rootstocks from resistant (KBH 2006/18) and susceptible (60444) varieties. CBSD symptoms appeared in susceptible 60444 rootstocks in the growing shoots after removal of the inoculating scion at 4 wag. Shoots from KBH 2006/18 rootstocks remained symptom-free. Furthermore, RT-qPCR quantitation of virus titers in storage roots of inoculated rootstocks confirmed the absence of CBSV (TAZ-DES-01) and UCBSV (TAZ-DES-02) in KBH 2006/18 at 8 weeks after removing the inoculating scion (Fig. 2). Propagation of the inoculated rootstock plants via stem cuttings resulted in a low percentage of cutting survival for 60444 compared with $\mathrm{KBH}$ 2006/18 (Supplementary Table S3). All established 60444 cuttings developed typical CBSD symptoms, while cuttings from KBH 2006/18 remained symptom-free.

\section{CBSD resistance holds}

\section{against different CBSV and UCBSV isolates.}

Resistance of KBH 2006/18 and KBH 2006/26 to CBSD was tested further using UCBSV (UG:Kab4-3:07) — a virus isolate from the epidemic area of Kabanyolo, Uganda (Mbanzibwa et al. 2011b; Mohammed et al. 2012). Top cleft-grafting on UCBSV (UG:Kab4-3:07)-infected AR34.2 roostocks was performed using 60444, KBH 2006/18, and KBH 2006/26 scions (Table 2, third column). UCBSV (UG:Kab4-3:07) titers were quantitated in the rootstock plants (Supplementary Fig. S4) and in the scions (Supplementary Fig. S5). High levels of UCBSV (UG:Kab4-3:07) titers could be detected in all susceptible scions but remained undetectable in the scions from KBH 2006/18 and KBH 2006/26 at 8 wag.

Additional testing using a side-grafting method according to Mohammed et al. (2012) was performed to assess resistance of KBH 2006/18 and KBH 2006/26 to mixed CBSV (MZ:Nam11:07) and UCBSV (UG:Kab4-3:07) infections (Table 2, fourth column). Accumulation of CBSV (MZ:Nam1-1:07) was detected in the susceptible 60444 plants at 8 wag (Supplementary Fig. S6). No virus could be detected in the resistant varieties even at 16 wag.
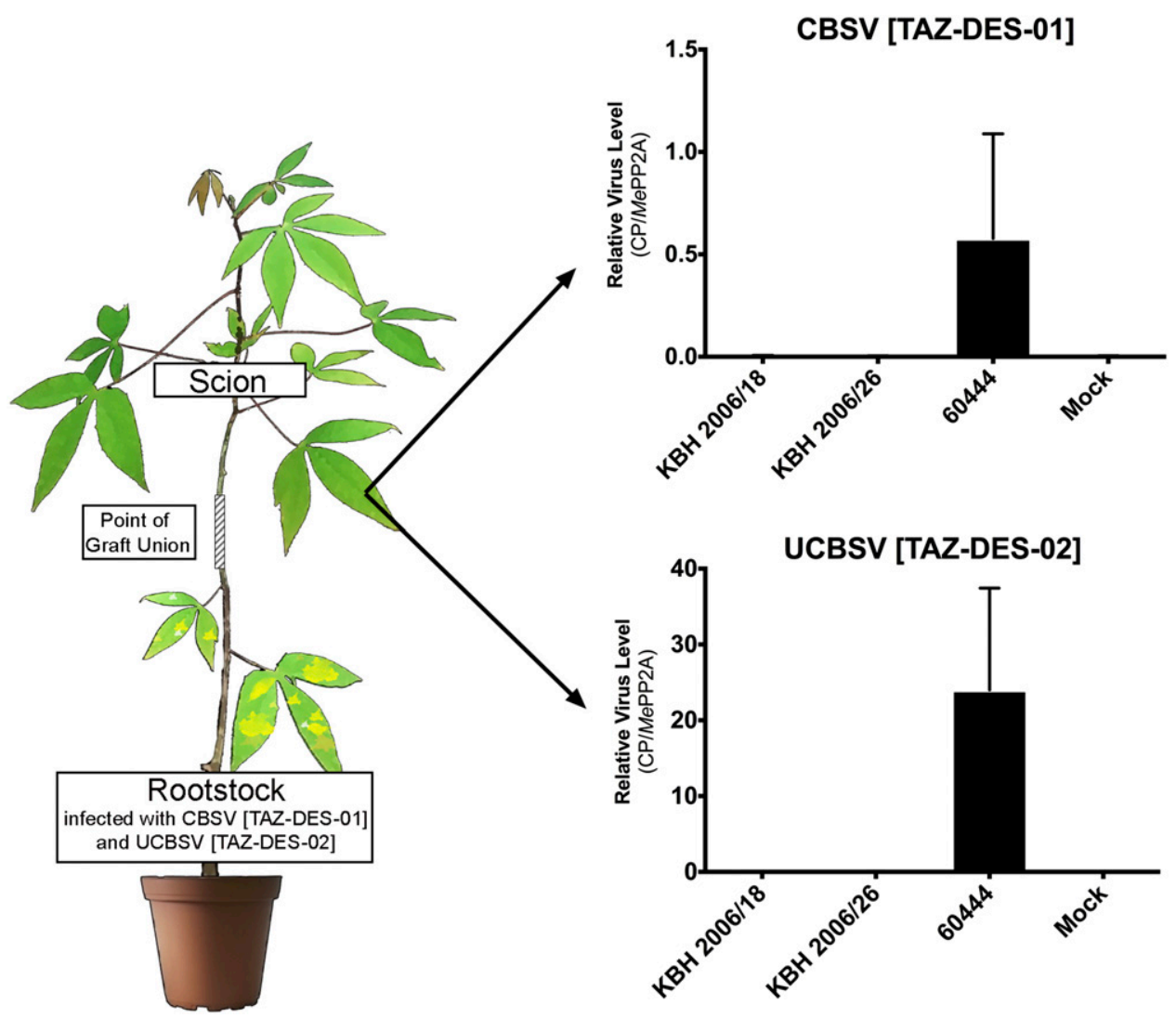

Fig. 1. Reverse transcription-quantitative polymerase chain reaction quantitation of virus titers in scions from selected accessions grafted on rootstocks carrying mixed Cassava brown streak virus (TAZ-DES-01) and Ugandan cassava brown streak virus (TAZ-DES-02) infection. The $y$ axis represents mean fold change of virus coat protein over $M e P P 2 A$. Error bars represent mean \pm standard deviation for three biological replicates. 
$\mathrm{KBH} 2006 / 18$ is resistant

to mixed CBSVs and CMG infection.

Co-occurrence of CBSD and CMD has been reported in the field (Alicai et al. 2007; Thresh et al. 1994). However, field data do not support synergism between CBSVs and CMGs (Legg et al. 2011). We inoculated KBH 2006/18 with a single CMG species (ACMV-NOg and EACMV-Ug, in independent infections) by using the top-grafting method. KBH 2006/18 scions remained symptom free and control 60444 scions displayed CMD symptoms at 2 wag for both viral species. In the same experiment, we also inoculated scions of the TME 7 landrace that was previously identified as CMD-resistant (Fregene et al. 2000; Raji et al. 2009). In contrast to KBH 2006/18 scions that remained symptom-free after CMD infection until the final observation stage at $24 \mathrm{wag}, \mathrm{CMD}$ symptoms appeared on the first emerging leaves of TME 7 scions inoculated with ACMVNog, followed by a recovery phenotype typical of CMD-tolerant cultivars. Subsequent viral DNA quantitation revealed that ACMV-NOg was detectable in both control 60444 and TME 7 scions, while EACMV-Ug viral particles were only detectable in 60444 control scions (Supplementary Fig. S7). Both ACMV-NOg and EACMV-Ug could not be detected in $\mathrm{KBH}$ 2006/18 scions.

In order to evaluate resistance of the KBH 2006/18 elite breeding line to a mixed CBSD and CMD infection, diseasefree KBH 2006/18 and 60444 scions were grafted on 60444 rootstocks carrying two combinations of CBSVs and CMGs: i)
EACMV-Ug + CBSV (TAZ-DES-01) + UCBSV (TAZ-DES-02) and ii) EACMV-Ug + UCBSV (UG:Kab4-3:07). Viral symptoms appeared in 60444 scions at 3 wag and CMD symptoms were prominent over CBSD symptoms. KBH 2006/18 scions did not show either CMD or CBSD symptoms. Virus detection at 8 wag in inoculated scions revealed that both EACMV-Ug and CBSVs could replicate in 60444 scions (Fig. 3). EACMV-Ug and CBSVs titers varied between scions. We also noticed that CBSV (TAZDES-01) was not detectable in the 60444 scions grafted on 60444 rootstocks carrying the EACMV-Ug, CBSV (TAZ-DES-01), and UCBSV (TAZ-DES-02) mixed infection (Fig. 3). Viruses used in the mixed infections were below the detection limit in $\mathrm{KBH}$ 2006/18 scions. We, therefore, concluded that CBSD resistance in the elite breeding line KBH 2006/18 holds even when inoculated with mixed infections of CBSVs and EACMV-Ug.

\section{CBSVs are transmitted through KBH 2006/18 scions.}

In order to test if the elite breeding line KBH 2006/18 restricts viral movement, we performed double-grafting experiments (Supplementary Fig. S8A). KBH 2006/18 and 60444 scions (referred to as first scions) were grafted on susceptible 60444 rootstocks infected with CBSV (TAZ-DES-01) and UCBSV (TAZ-DES-02). Following graft establishment and stem hardening, uninfected 60444 scions (referred to as second scions) were grafted onto the established first scions. When grafted on 60444 first scions, 60444 second scions developed typical CBSD symptoms as early as 4 wag. When grafted on
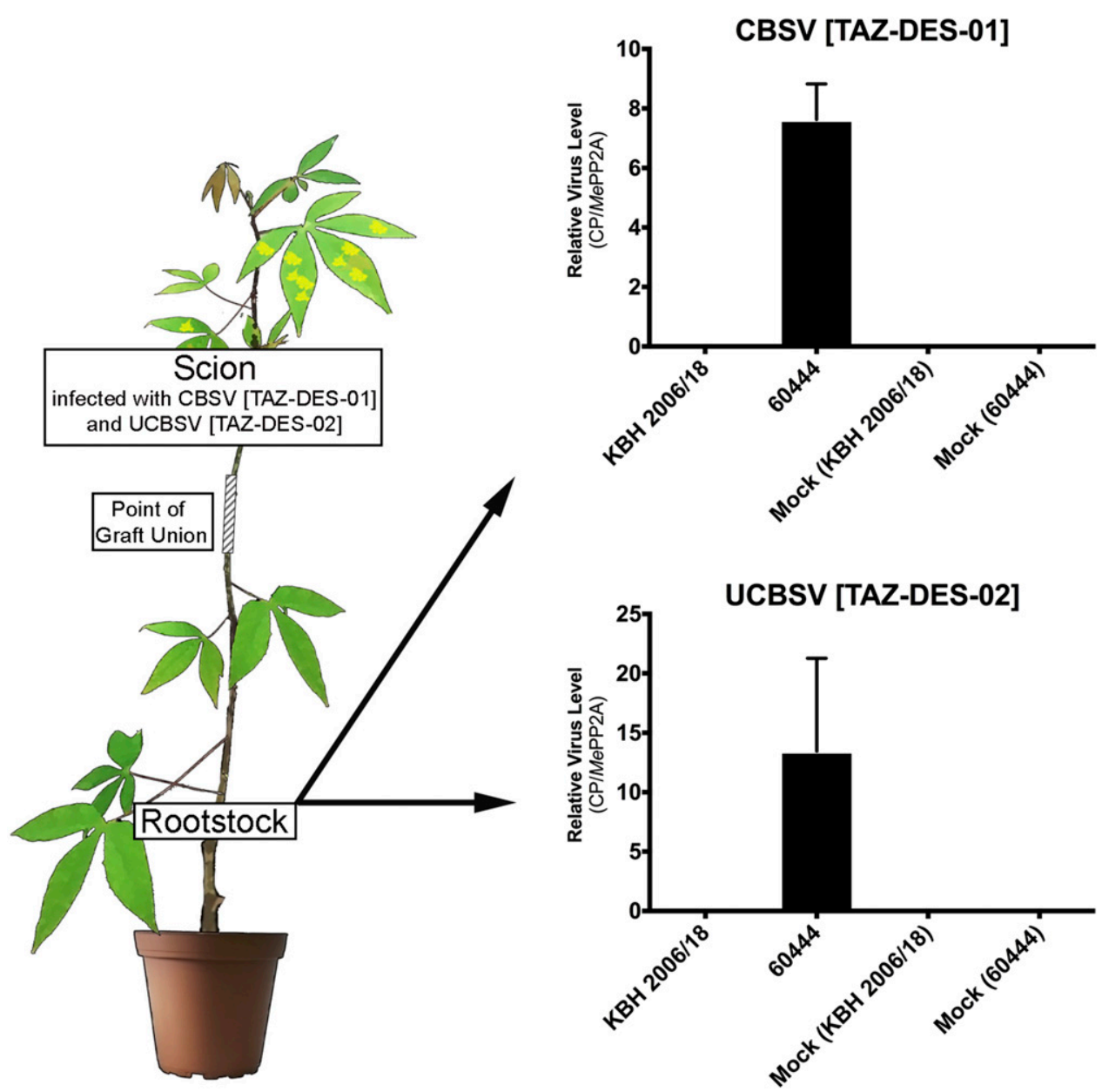

Fig. 2. Reverse transcription-quantitative polymerase chain reaction quantitation of virus titers in rootstocks from selected accessions inoculated with scions carrying mixed Cassava brown streak virus (TAZ-DES-01) and Ugandan cassava brown streak virus (TAZ-DES-02) infection. The $y$ axis represents fold change of virus coat protein over $M e P P 2 A$. Error bars represent mean \pm standard deviation for three biological replicates. 
KBH 2006/18 first scions, CBSD symptoms in the 60444 second scions only appeared at $10 \mathrm{wag}$. CBSV (TAZ-DES-01) and UCBSV (TAZ-DES-02) were detectable in 60444 first scions but could not be detected in KBH 2006/18 first scions (Supplementary Fig. S9). Consistent with symptom development, CBSV (TAZ-DES-01) and UCBSV (TAZ-DES-02) could be detected in 60444 second scions grafted on 60444 first scions at 4 wag. UCBSV (TAZ-DES-02) could also be detected in 60444 second scions grafted on KBH 2006/18 first scions at 4 wag, even though these second scions were nonsymptomatic. Eventually, CBSD symptoms were observed on 60444 second scions from all the grafts at 10 wag. The double-grafting experiment clearly indicates that both susceptible and resistant varieties allow movement of CBSV (TAZ-DES-01) and UCBSV (TAZ-DES-02) through the stem.

In an independent double-grafting experiment, we observed that susceptible second scions grafted onto a CBSD-resistant transgenic 60444 (60444-hp9) (Vanderschuren et al. 2012) first scion developed CBSD symptoms at 10 weeks after grafting. In contrast, susceptible second scions grafted onto control 60444-wt scions developed symptoms at 4 weeks after grafting. The similarity in results of double-grafting experiments with 60444-hp9 and KBH 2006/18 first scions suggests that those two genetic backgrounds do not differ in restriction of CBSV movement. Our results also suggest that KBH 2006/18 and 60444-Hp 9 have similar resistance levels to CBSV infections since both CBSV (TAZ-DES01) and UCBSV (TAZ-DES-02) remained undetectable in the leaves and stems of KBH 2006/18 and 60444-Hp 9 first scions.

\section{Virus replication is inhibited in $\mathrm{KBH} 2006 / 18$ protoplasts.}

To further elucidate the mode of resistance exhibited by $\mathrm{KBH}$ $2006 / 18$, we assayed virus replication in leaf mesophyll protoplasts at $6 \mathrm{~h}$ posttransfection. We extracted virions (Berger and Shiel 1998) from greenhouse-grown 60444 cassava plants infected with CBSV (TAZ-DES-01) and UCBSV (TAZ-DES-02) and transfected the virion extract into protoplasts obtained from 60444 and KBH 2006/18 leaves (Yoo et al. 2007). RT-qPCR quantitation of relative virus (CBSV (TAZ-DES-01) and UCBSV (TAZ-DES-02) levels indicated that virus levels increased in
60444 protoplasts over the duration of the experiment. In contrast, UCBSV (TAZ-DES-02) and CBSV (TAZ-DES-01) levels decreased in $\mathrm{KBH} 2006 / 18$ protoplasts at $6 \mathrm{~h}$ posttransfection (Fig. 4). The results of the protoplast replication assay suggest that the characterized CBSD resistance in the KBH 2006/18 elite breeding line is at least partially based on inhibition of one or several steps following virus entry in the cell, from uncoating to genome amplification.

\section{DISCUSSION}

Natural CBSD resistance is key to control CBSD in African regions, where it has become a major constraint to cassava production. This is also critical to minimize the threat of dissemination to regions where CBSD is currently absent. Diagnostics and precise characterization of virus resistance require standard procedures and terminology that need to be commonly accepted to allow selection and utilization of plant material by virologists and plant breeders. The use of terms for plant responses to virus inoculation has long been debated (Cooper and Jones 1983). Here, we used a stringent top cleft-grafting method for inoculation of selected cassava cultivars and elite breeding lines with CBSV infections. Our virus inoculation method resulted in $100 \%$ infection rates in the susceptible 60444 scions in all experiments. Infection rates obtained by the top-grafting method are more consistent and reproducible compared with other inoculation methods reported to date (Maruthi et al. 2005; Mohammed et al. 2012; Ogwok et al. 2012). Because the topgrafting method provides a constant virus inoculum from the infected rootstock to the scion, it also allows the assessment of resistance over several weeks of inoculation. Using a mixed CBSV and UCBSV infection, we identified two cassava elite breeding lines (i.e., KBH 2006/18 and KBH 2006/26) that remained symptom-free even at 16 wag. Cultivar TMS 30001 only developed inconspicuous CBSD symptoms but CBSV accumulated in scions developing disease symptoms.

CBSD-infected susceptible varieties usually develop a dry brown-black necrotic rot of the tuberous roots. Despite

A

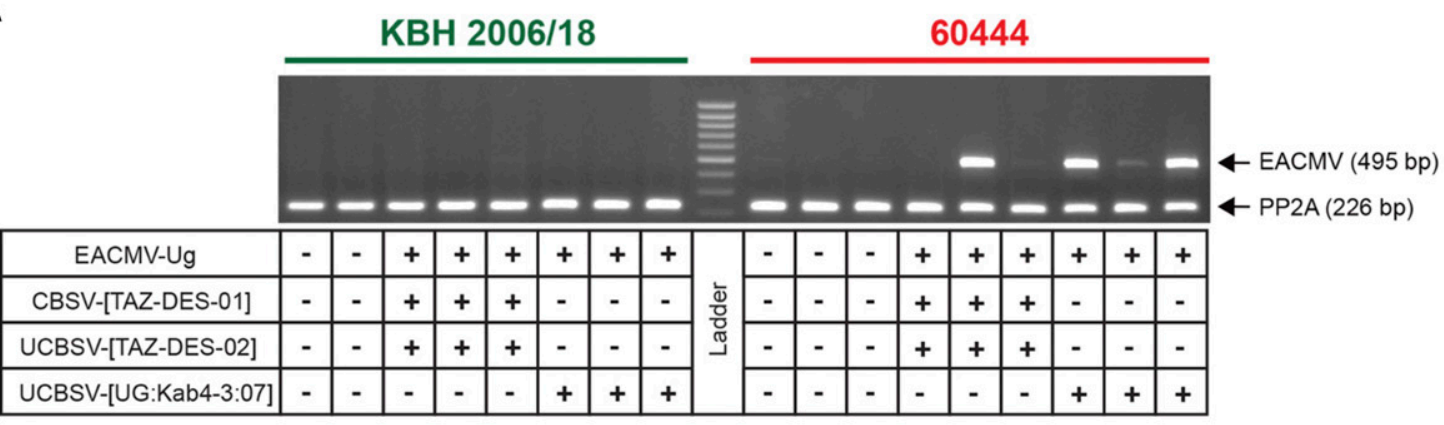

B

KBH 2006/18

60444

\begin{tabular}{|c|c|c|c|c|c|c|c|c|c|c|c|c|c|c|c|c|c|c|c|c|c|c|c|c|}
\hline \multirow[b]{2}{*}{ EACMV-Ug } & & \multicolumn{10}{|c|}{$=-\overline{1}=$} & \multicolumn{12}{|c|}{ 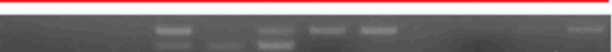 } & $\begin{array}{l}\text { UCBSV (440 bp) } \\
-\operatorname{CBSV}(330 \mathrm{bp}) \\
-\mathrm{PP} 2 A(150 \mathrm{bp})\end{array}$ \\
\hline & - & - & - & - & - & + & + & + & + & + & + & - & - & - & - & - & - & + & + & + & + & + & + & \\
\hline CBSV-[TAZ-DES-01] & - & - & + & + & + & + & + & + & - & - & - & - & - & - & + & + & + & + & + & + & - & - & - & \\
\hline UCBSV-[TAZ-DES-02] & - & - & + & + & + & + & + & + & - & - & - & - & - & - & + & + & + & + & + & + & - & - & - & \\
\hline UCBSV-[UG:Kab4-3:07]] & - & - & - & - & - & - & - & - & + & + & + & - & - & - & - & - & - & - & - & - & + & + & + & \\
\hline
\end{tabular}

Fig. 3. Virus detection in KBH 2006/18 and 60444 scions grafted on 60444 rootstocks carrying mixed strains of Cassava brown streak virus (CBSV) and geminivirus infection at 8 weeks after grafting. + and - indicate absence and presence of listed virus isolates in 60444 rootstocks. A, Multiplex polymerase chain reaction (PCR) with East African cassava mosaic virus (EACMV)-AC1 and PP2A primers. B, Reverse transcription-PCR with primers CBSDDF2 and CBSDDR. 
evidence that CBSV infections accumulate in symptomatic and nonsymptomatic root tissues (Abarshi et al. 2010; Moreno et al. 2011), the role of root organs in CBSV replication and cycle has not yet been elucidated. Studies in other plant-virus systems suggest that virus accumulation is not homogenous in root systems and that primary roots can sustain a high level of virus replication (Dalmay et al. 2000; Valentine et al. 2002). Side-grafting and top-grafting experiments with CBSV-infected 60444 scions on virus-free $\mathrm{KBH}$ 2006/18 rootstocks confirmed that the KBH 2006/18 rootstocks are also resistant to CBSV infections. Cumulatively, our data show that the top-grafting method is suitable for identification of CBSD resistance and that resistance against the mixed CBSV-UCSBV infections used in our screen was robust in two elite breeding lines.

CBSV and UCBSV differ in their virulence on cassava cultivars (Mohammed et al. 2012; Winter et al. 2010). We, therefore, used different combinations of CBSV and UCBSV isolates to assess the stability of the CBSD resistance. KBH 2006/18 and KBH 2006/26 remained symptom-free with all combinations of virus isolates and inoculation methods.

Successful virus disease management of vegetatively propagated crop requires the selection of symptomless cultivars that do not support virus replication and accumulation (van den Bosch et al. 2007). Therefore, characterization of plant responses to virus diseases requires molecular quantitation of virus titers in inoculated plants. CBSV and UCBSV were near or below the detection limit in KBH 2006/18 and KBH 2006/26, indicating that these elite breeding lines qualify as resistant (Cooper and Jones 1983). Comparison of cycle threshold $(\mathrm{Ct})$ values obtained in RT-qPCR assays of mock controls and inoculated scions of KBH 2006/18 suggests that CBSV and UCBSV do not replicate in leaves of this variety.

Our results also demonstrate that coinoculation of CBSV strains with a severe CMG isolate does not break CBSD resistance in the resistant elite breeding lines. Moreover, coinoculation does not affect the ratio of the CBSD virus isolates initially present in the susceptible cassava 60444 line, suggesting that both types of viruses do not interfere with their respective replication mechanisms.

Based on the results of our double-grafting experiment, it appears that KBH 2006/18 can transmit CBSV infections. The susceptibility of a plant to virus infection depends on both the ability of the virus to gain access to the phloem long-distance transport (German-Retana et al. 2000; Wang et al. 1999) as well as host factors, such as restricted Tobacco etch virus movement (RTM) proteins (Chisholm et al. 2001; Cosson et al. 2010), that permit or inhibit viral movement in vascular tissues. However, the results of double-grafting experiments with KBH 2006/18 and a CBSD-resistant transgenic 60444 line (60444-hp9) (Vanderschuren et al. 2012) did not reveal any significant difference, as both genotypes were able to transmit CBSV infections to susceptible second scions and at similar time points after grafting. Examining virus replication at
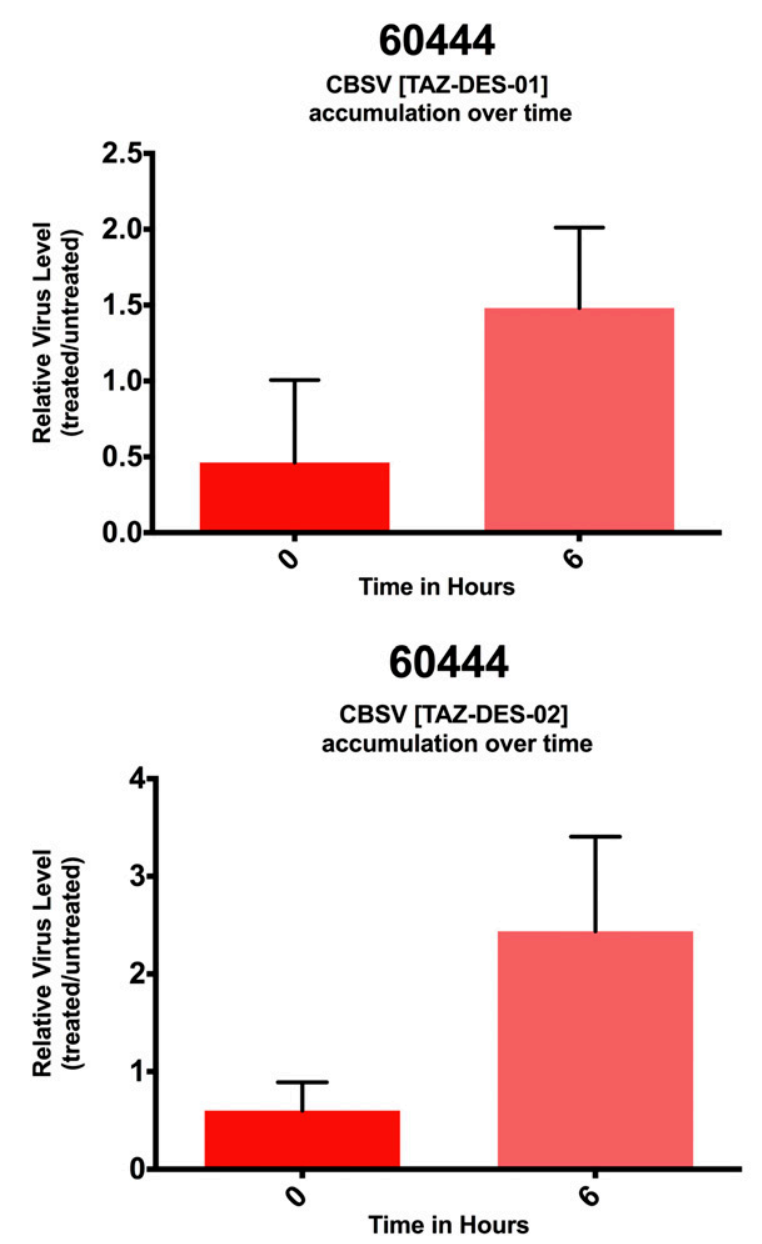
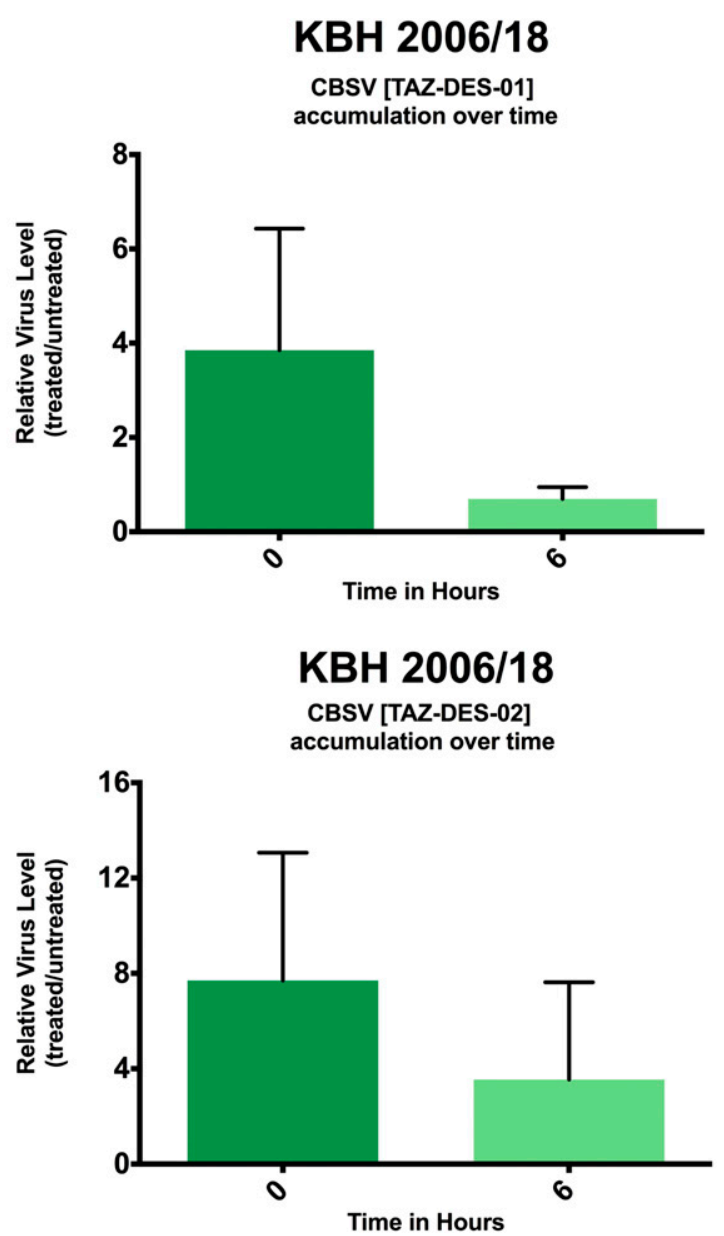

Fig. 4. Reverse transcription-quantitative polymerase chain reaction quantitation of Cassava brown streak virus (CBSV) (TAZ-DES-01) and $U$ gandan cassava brown streak virus (TAZ-DES-02) (relative to MePP2A) from transfected protoplasts over time. Virus levels are expressed as fold change over control (non-polyethylene glycol transformed) values to account for only successful transfection events. Error bars represent mean \pm standard deviation for a minimum of three biological replicates. 
the cellular level using cassava leaf mesophyll protoplasts also revealed that the CBSV (TAZ-DES-01) and UCBSV (TAZDES-02) titers initially transfected to $\mathrm{KBH} 2006 / 18$ protoplasts decline over time. On the contrary, both virus isolates had increasing titers over time in 60444 protoplasts. While our protoplast assay results suggest an intracellular activity against both CBSV (TAZ-DES-01) and UCBSV (TAZ-DES-02) isolates, the key virus replication steps, from uncoating to genome amplification, inhibited in the KBH 2006/18 elite breeding line remained to be identified. The cassava protoplast assay established in the present study will be instrumental to further characterize the presented CBSD resistance. Future characterization of the CBSD resistance in KBH 2006/18 and KBH 2006/26 will also require the development of CBSV and UCBSV infectious clones to determine viral mutations that can overcome the CBSD resistance reported in the present study.

In addition, analysis of cassava varieties with contrasting CBSD resistance using genome sequencing and transcriptome profiling could be particularly instrumental in identifying genes and their expression patterns that are keys for compatible and incompatible interactions in the CBSV-cassava pathosystem. Furthermore, isolation of CBSV isolates capable of breaking CBSD resistance in $\mathrm{KBH}$ 2006/18 and KBH 2006/26 elite breeding lines will also provide further insights into CBSV virulence factors.

\section{MATERIALS AND METHODS}

Plant material and virus isolates.

Disease-free varieties and elite cassava breeding lines used for the study were obtained from international and national research institutes in Africa as well as lines from ongoing breeding programs. Cassava plants were grown under greenhouse conditions $\left(27^{\circ} \mathrm{C}, 16 \mathrm{~h}\right.$ of light, $60 \%$ humidity). The virus isolates were obtained from field-infected cassava plants. Mixed infections were generated through grafting and subsequent propagation of scions carrying mixed infections.

\section{Virus inoculation method.}

Individual plants were assessed for their viral resistance by using the top cleft-grafting procedure and side-grafting method as previously described (Mohammed et al. 2012). Mock plants consisted of disease-free scions grafted onto disease-free rootstocks. The double-grafting procedure involved establishment of the first scion for 14 weeks and subsequent grafting of a second scion following the top cleft-grafting procedure. CBSD symptoms were observed at 12 weeks for the plants derived from scions propagated via stem cuttings.

Lower and upper stem samples from 1st scion corresponded to the stem sections 15 to 20 centimeters and 20 to 25 centimeters above the point of grafting, respectively. For detection of CBSVs in the lower and upper stem sections of KBH 2006/18, 60444-Hp 9 and 60444, the bark of the stems were removed to have a larger fraction of vascular tissues in the samples.

\section{Virus titer quantitation.}

Total RNA was extracted from leaf samples using a protocol modified from a pine tree RNA extraction protocol (Chang et al. 1993; Moreno et al. 2011). First-strand cDNA was synthesized according to the manufacturer instructions (Fermentas, Vilnius, Lithuania) with random hexamer primer mix and $1 \mu \mathrm{g}$ of total RNA in a final reaction volume of $20 \mu \mathrm{l}$. Real-time PCR reactions were performed with the 7500 Fast real time PCR system (Applied biosystems, Foster City, CA, U.S.A.), using the SDS software. Virus titers were quantitated relative to internal control $M e P P 2 A$, as previously described (Moreno et al. 2011). All primers used for virus detection and internal control are listed in Supplementary Table S4.

\section{Virion extraction.}

CBSV and UCBSV virions were extracted from 20 to $80 \mathrm{~g}$ of greenhouse-grown, infected leaf material following an adapted potyvirus extraction protocol, as described by Berger and Shiel (1998).

\section{Protoplast isolation and transfection.}

Cassava leaf mesophyll protoplasts were extracted from mature leaves of in vitro-grown 60444 and $\mathrm{KBH}$ 2006/18 plants and transfected following the Arabidopsis leaf mesophyll protoplast transfection protocol developed by Yoo and colleagues (2007). Total RNA extraction using Isol-RNA (5Prime $\mathrm{GmbH}$ ) at a ratio of $200 \mu \mathrm{l}$ of Isol-RNA solution per two million protoplasts was performed. Virus level quantitation was performed as described above. Due to the low amount of RNA obtained in some samples, a cut-off of $M e P P 2 A \mathrm{Ct}<30$ was applied to all samples.

\section{ACKNOWLEDGMENTS}

The authors thank I. Zurkirchen (ETH Zurich) for special care of the cassava plants in the glasshouse and A. Alder (ETH Zurich) for geminivirus inoculation. S. Bull (ETH Zurich) and J. Kuon (ETH Zurich) are acknowledged for useful comments on the manuscript. The authors thank H. Nawabu (International Institute of Tropical Agriculture) for collecting plant material in the field. We gratefully acknowledge the support of our work by ETH Zürich. R. B. Anjanappa is supported by the Research Fellow Partnership Programme (ETH North-South Centre). D. Mehta is supported by the European Union's Seventh Framework Programme for research, technological development, and demonstration under grant agreement number GA-2013-608422-IDP BRIDGES.

\section{LITERATURE CITED}

Abarshi, M. M., Mohammed, I. U., Wasswa, P., Hillocks, R. J., Holt, J., Legg, J. P., Seal, S. E., and Maruthi, M. N. 2010. Optimization of diagnostic RT-PCR protocols and sampling procedures for the reliable and cost-effective detection of Cassava brown streak virus. J. Virol. Methods 163:353-359.

Abarshi, M. M., Mohammed, I. U., Jeremiah, S. C., Legg, J. P., Kumar, P. L., Hillocks, R. J., and Maruthi, M. N. 2012. Multiplex RT-PCR assays for the simultaneous detection of both RNA and DNA viruses infecting cassava and the common occurrence of mixed infections by two cassava brown streak viruses in East Africa. J. Virol. Methods 179:176-184.

Alicai, T., Omongo, C. A., Maruthi, M. N., Hillocks, R. J., Baguma, Y., Kawuki, R., Bua, A., Otim-Nape, G. W., and Colvin, J. 2007. Re-emergence of cassava brown streak disease in Uganda. Plant Dis. 91:24-29.

Berger, P. H., and Shiel, P. J. 1998. Potyvirus isolation and RNA extraction. Pages 151-160 in: Plant Virology Protocols. G. D. Foster, and S. C. Taylor, eds. Humana Press Inc, Totowa, NJ, U.S.A.

Bigirimana, S., Barumbanze, P., Ndayihanzamaso, P., Shirima, R., and Legg, J. P. 2011. First report of cassava brown streak disease and associated Ugandan cassava brown streak virus in Burundi. New Dis. Rep. 24:26

Chang, S., Puryear, J., and Cairney, J. 1993. A simple and efficient method for isolating RNA from pine trees. Plant Mol. Biol. Report. 11:113-116.

Chisholm, S. T., Parra, M. A., Anderberg, R. J., and Carrington, J. C. 2001 Arabidopsis $R T M 1$ and $R T M 2$ genes function in phloem to restrict longdistance movement of tobacco etch virus. Plant Physiol. 127:1667-1675.

Cooper, J. I., and Jones, A. T. 1983. Responses of plants to viruses-Proposals for the use of terms. Phytopathology 73:127-128.

Cosson, P., Sofer, L., Le, Q. H., Leger, V., Schurdi-Levraud, V., Whitham, S. A., Yamamoto, M. L., Gopalan, S., Le Gall, O., Candresse, T., Carrington, J. C., and Revers, F. 2010. RTM3, which controls longdistance movement of potyviruses, is a member of a new plant gene family encoding a meprin and TRAF homology domain-containing protein. Plant Physiol. 154:222-232.

Catholic Relief Services. 2012. Page 137 in: Great Lakes Cassava Initiative Final Report. Catholic Relief Services, Baltimore, MD, U.S.A. http:// static1.1.sqspcdn.com/static/f/752898/20413731/1348594436053/glci-finalreport.pdf?token=zcj1E7xfQapCnEXXnvS6sSOvUu4=

Dalmay, T., Hamilton, A., Mueller, E., and Baulcombe, D. C. 2000. Potato virus $X$ amplicons in arabidopsis mediate genetic and epigenetic gene silencing. Plant Cell 12:369-379. 
Fermont, A. M., Babirye, A., Obiero, H. M., Abele, S., and Giller, K. E. 2010. False beliefs on the socio-economic drivers of cassava cropping. Agron. Sustain. Dev. 30:433-444.

Fregene, M., Bernal, A., Duque, M., Dixon, A., and Tohme, J. 2000. AFLP analysis of African cassava (Manihot esculenta Crantz) germplasm resistant to the cassava mosaic disease (CMD). Theor. Appl. Genet. 100: 678-685.

German-Retana, S., Candresse, T., Alias, E., Delbos, R. P., and Le Gall, O. 2000. Effects of green fluorescent protein or $\beta$-glucuronidase tagging on the accumulation and pathogenicity of a resistance-breaking Lettuce mosaic virus isolate in susceptible and resistant lettuce cultivars. Mol. Plant-Microbe Interact 13:316-324.

Hillocks, R. J., Raya, M., and Thresh, J. M. 1996. The association between root necrosis and above-ground symptoms of brown streak virus infection of cassava in southern Tanzania. Int. J. Pest Manage. 42:285-289.

Hillocks, R. J., Raya, M. D., Mtunda, K., and Kiozia, H. 2001. Effects of brown streak virus disease on yield and quality of cassava in Tanzania. J. Phytopathol. 149:389-394.

Jennings, D. L., and Iglesias, C. 2002. Breeding for Crop Improvement. Pages 149-166 in: Cassava: Biology, Production, Utilization, R. J. Hillocks, J. M. Thresh, and A. C. Bellotti, eds. CABI, Wallingford, U.K.

Legg, J. P., Owor, B., Sseruwagi, P., and Ndunguru, J. 2006. Cassava mosaic virus disease in East and central Africa: Epidemiology and management of a regional pandemic. Adv. Virus Res. 67:355-418.

Legg, J. P., Jeremiah, S. C., Obiero, H. M., Maruthi, M. N., Ndyetabula, I., Okao-Okuja, G., Bouwmeester, H., Bigirimana, S., Tata-Hangy, W., Gashaka, G., Mkamilo, G., Alicai, T., and Lava Kumar, P. 2011. Comparing the regional epidemiology of the cassava mosaic and cassava brown streak virus pandemics in Africa. Virus Res. 159:161-170.

Lister, R. M. 1959. Mechanical transmission of cassava brown streak virus. Nature 183:1588-1589.

Maruthi, M. N., Hillocks, R. J., Mtunda, K., Raya, M. D., Muhanna, M., Kiozia, H., Rekha, A. R., Colvin, J., and Thresh, J. M. 2005. Transmission of Cassava brown streak virus by Bemisia tabaci (Gennadius). J. Phytopathol. 153:307-312.

Mbanzibwa, D. R., Tian, Y., Mukasa, S. B., and Valkonen, J. P. 2009a. Cassava brown streak virus (Potyviridae) encodes a putative Maf/HAM1 pyrophosphatase implicated in reduction of mutations and a P1 proteinase that suppresses RNA silencing but contains no HC-Pro. J. Virol. 83: 6934-6940.

Mbanzibwa, D. R., Tian, Y. P., Tugume, A. K., Mukasa, S. B., Tairo, F., Kyamanywa, S., Kullaya, A., and Valkonen, J. P. 2009b. Genetically distinct strains of Cassava brown streak virus in the Lake Victoria basin and the Indian Ocean coastal area of East Africa. Arch. Virol. 154: 353-359.

Mbanzibwa, D. R., Tian, Y. P., Tugume, A. K., Mukasa, S. B., Tairo, F., Kyamanywa, S., Kullaya, A., and Valkonen, J. P. T. 2011a. Simultaneous virus-specific detection of the two cassava brown streak-associated viruses by RT-PCR reveals wide distribution in East Africa, mixed infections, and infections in Manihot glaziovii. J. Virol. Methods 171: 394-400.

Mbanzibwa, D. R., Tian, Y. P., Tugume, A. K., Patil, B. L., Yadav, J. S., Bagewadi, B., Abarshi, M. M., Alicai, T., Changadeya, W., Mkumbira, J., Muli, M. B., Mukasa, S. B., Tairo, F., Baguma, Y., Kyamanywa, S. Kullaya, A., Maruthi, M. N., Fauquet, C. M., and Valkonen, J. P. T. 2011b. Evolution of cassava brown streak disease-associated viruses. J. Gen. Virol. 92:974-987.

Mohammed, I. U., Abarshi, M. M., Muli, B., Hillocks, R. J., and Maruthi, M. N. 2012. The symptom and genetic diversity of cassava brown streak viruses infecting cassava in East Africa. Adv. Virol. 2012:795697.

Monger, W. A., Seal, S., Isaac, A. M., and Foster, G. D. 2001. Molecular characterization of the Cassava brown streak virus coat protein. Plant Pathol. 50:527-534

Monger, W. A., Alicai, T., Ndunguru, J., Kinyua, Z. M., Potts, M., Reeder, R. H., Miano, D. W., Adams, I. P., Boonham, N., Glover, R. H., and
Smith, J. 2010. The complete genome sequence of the Tanzanian strain of Cassava brown streak virus and comparison with the Ugandan strain sequence. Arch. Virol. 155:429-433.

Moreno, I., Gruissem, W., and Vanderschuren, H. 2011. Reference genes for reliable potyvirus quantitation in cassava and analysis of Cassava brown streak virus load in host varieties. J. Virol. Methods 177:49-54.

Mulimbi, W., Phemba, X., Assumani, B., Muyisa, S., Ugentho, H., Reeder, R., Legg, J. P., Laurenson, L., Weekes, R., and Thom, F. E. F. 2012. First report of Ugandan cassava brown streak virus on cassava in Democratic Republic of Congo. New Dis. Rep. 26:11.

Ndunguru, J., Sseruwagi, P., Tairo, F., Stomeo, F., Maina, S., Djinkeng, A., Kehoe, M., and Boykin, L. M. 2015. Analyses of twelve new whole genome sequences of cassava brown streak viruses and Ugandan cassava brown streak viruses from East Africa: Diversity, supercomputing and evidence for further speciation. PLoS One 10:e0139321.

Ogwok, E., Odipio, J., Halsey, M., Gaitan-Solis, E., Bua, A., Taylor, N. J., Fauquet, C. M., and Alicai, T. 2012. Transgenic RNA interference (RNAi)-derived field resistance to cassava brown streak disease. Mol Plant Pathol. 13:1019-1031.

Otim-Nape, G.W., Thresh, J. M., and Shaw, M. W. 1997. The effects of cassava mosaic virus disease on yield and compensation in mixed stands of healthy and infected cassava. Ann. Appl. Biol. 130:503-521.

Patil, B. L., and Fauquet, C. M. 2009. Cassava mosaic geminiviruses: Actual knowledge and perspectives. Mol. Plant Pathol. 10:685-701.

Patil, B. L., Legg, J. P., Kanju, E., and Fauquet, C. M. 2015. Cassava brown streak disease: A threat to food security in Africa. J. Gen. Virol. 96: 956-968.

Raji, A. A. J., Anderson, J. V., Kolade, O. A., Ugwu, C. D., Dixon, A. G. O., and Ingelbrecht, I. L. 2009. Gene-based microsatellites for cassava (Manihot esculenta Crantz): Prevalence, polymorphisms, and cross-taxa utility. BMC Plant Biol. 9:1-11.

Seif, A. A. 1982. Effect of cassava mosaic virus on yield of cassava. Plant Dis. 66:661-662.

Thresh, J. M., and Cooter, R. J. 2005. Strategies for controlling cassava mosaic virus disease in Africa. Plant Pathol. 54:587-614.

Thresh, J. M., Fargette, D., and Otim-Nape, G. W. 1994. The viruses and virus diseases of cassava in Africa. Afr. Crop Sci. J. 2:459-478.

Tomlinson, J. A., Ostoja-Starzewska, S., Adams, I. P., Miano, D. W., Abidrabo, P., Kinyua, Z., Alicai, T., Dickinson, M. J., Peters, D., Boonham, N., and Smith, J. 2013. Loop-mediated isothermal amplification for rapid detection of the causal agents of cassava brown streak disease. J. Virol. Methods 191:148-154.

Valentine, T. A., Roberts, I. M., and Oparka, K. J. 2002. Inhibition of tobacco mosaic virus replication in lateral roots is dependent on an activated meristem-derived signal. Protoplasma 219:184-196.

van den Bosch, F., Jeger, M. J., and Gilligan, C. A. 2007. Disease control and its selection for damaging plant virus strains in vegetatively propagated staple food crops; a theoretical assessment. Proc. Biol. Sci. 274:11-18.

Vanderschuren, H., Moreno, I., Anjanappa, R. B., Zainuddin, I. M., and Gruissem, W. 2012. Exploiting the combination of natural and genetically engineered resistance to cassava mosaic and cassava brown streak viruses impacting cassava production in Africa. PLoS One 7.

Wang, H. L., Sudarshana, M. R., Gilbertson, R. L., and Lucas, W. J. 1999. Analysis of cell-to-cell and long-distance movement of a bean dwarf mosaic geminivirus-green fluorescent protein reporter in host and nonhost species: Identification of sites of resistance. Mol Plant Microbe Interact. 12:345-355

Winter, S., Koerbler, M., Stein, B., Pietruszka, A., Paape, M., and Butgereitt, A. 2010. Analysis of cassava brown streak viruses reveals the presence of distinct virus species causing cassava brown streak disease in East Africa. J. Gen. Virol. 91:1365-1372.

Yoo, S. D., Cho, Y. H., and Sheen, J. 2007. Arabidopsis mesophyll protoplasts: A versatile cell system for transient gene expression analysis. Nat. Protoc. 2: 1565-1572. 